\title{
PHENOMENOLOGY AS A POSSIBILITY OF SOCIAL THOUGHT
}

\section{ELŻBIETA HAŁAS [ED.], LIFE-WORLD, INTERSUBJECTIVITY AND CULTURE: CONTEMPORARY DILEMMAS}

Dorota Wolska

University of Wrocław

A subsequent volume in the series "Studies in Sociology: Symbols, Theory and Society" is dedicated to the memory of Richard Helmut Grathoff (1934-2013), a German scholar noted for preserving and developing phenomenological heritage in social thought. In the monograph on post-war German philosophy, Gérard Raulet remarked that it was Grathoff who, with Thomas Luckmann and Peter L. Berger, restored the work of Alfred Schütz - the pioneer of the phenomenological perspective in sociology - to the German episteme (2006: 38). Grathoff is also an influential scholar for Polish sociological thought. In the opening essay of the volume, Zdzisław Krasnodębski discusses the multidimensionality of Grathoff's merit. Krasnodębski remarks that his essay is more personal and sentimental than strictly academic, as is reflected in the title: "Grathoff's LifeWorld." It was Edmund Husserl's concept of the life-world (Lebenswelt) - as prominently and predominately interpreted by Schütz - that became key for conducting phenomenological social research. This volume, which was edited by Elżbieta Hałas and features Polish and foreign authors, including Grathoff's students and collaborators, addresses the need to rethink the concepts of Lebenswelt and intersubjectivity within the context of contemporary sociological thought.

The relevance and prospects of phenomenology - understood as a philosophical current and a research orientation in the social sciences 
and humanities - have for many years been a subject of ongoing debate. In the 1960s, Martin Heidegger, in his tellingly entitled essay "My Way to Phenomenology," summarised his attitude to this philosophical direction. Although Heidegger considered phenomenology's time to be over, he suggested treating it as a "possibility of thinking" which is changing over time and thus remaining open. He valued this possibility more than any "institution" of a philosophical current (Heidegger 1969: 90). Paul Ricoeur, who suggested that "phenomenology is first and foremost a history of Husserlian heresies," underlined its open and historical dimension in a different manner (see Raulet 2006: 39). In his academic handbook on phenomenology, Jean-François Lyotard wrote defensively about phenomenological style - a term he borrowed from Jean Wahl - arguing that the sense of phenomenology is constantly being created (Lyotard 1991). Nonetheless, Lyotard was convinced that phenomenology played a great role both for understanding the new subject of the humanities and social sciences, and the practice thereof.

Certainly, phenomenology as a possibility of thinking has been realised in different domains in different ways. Ferdinand Fellmann regards it as a science of structures, a type of cognitive psychology (it is important, however, to point to the differences of influence between Husserl's early and late philosophy). A phenomenological orientation is still vividly present in cultural anthropology, which is interested in the question of experience. It is also a source of inspiration for neuroscientists (see F. Varela). Life-World, Intersubjectivity and Culture: Contemporary Dilemmas provides insight into the present condition of phenomenological thought in social research, including processes of social and cultural transformations. ${ }^{1}$ Grathoff's ideas remain a source of inspiration and a subject of lively discussions for many contributors to this volume.

Thomas S. Eberle, a Swiss researcher and one of the authors of the first, meta-theoretical part of the volume ("Interpretative Perspectives on the Life-World"), is convinced that the phenomenological orientation in sociology is alive and well. He proposes a certain arrangement of the field of relationships between phenomenology and sociology, or more specifically, between a phenomenological life-world analysis and interpretative sociology. This topography is marked by three "points" - three theoretical approaches with their prominent figures and geographical spheres of influence. The first one, with Luckmann as the key figure, differentiates

${ }^{1}$ This is also the title of an international conference organised in Warsaw in September 2014 and attended by Grathoff's students and collaborators. 
between philosophical analysis and sociological research while emphasising the need for their compatibility. In this perspective, phenomenological life-world analysis is understood as "protosociology." This approach - argues Eberle - reflects Schütz's intentions by regarding phenomenology as a potential foundation for sociological methodology but objects to its simple and naive application. Schütz sought the foundation of empirical sociology not in transcendental phenomenology but in the constitutive phenomenology of the natural attitude. This required a certain "mediation" of philosophical anthropology and thus references to Max Scheler. As Eberle argues in great detail, Berger and Luckmann's The Social Construction of Reality is an excellent illustration of the compatibility of phenomenological analysis and sociology. Eberle considers that the work remains worthy of interest and research application - a statement that is difficult to argue with. Eberle observes that the above approach remains prominent in Germany, and more generally Europe, while a different approach achieved prominence in America. Its most remarkable representative is George Psathas, whose concept of "phenomenological sociology" - understood as a novel, not yet fully realised, sociological paradigm - was designed as an antidote to positivist sociology. Eberle demonstrates that although Psathas maintains his separateness from ethnomethodology, he remains under the powerful influence of this tradition. The third approach - which oscillates between the two previous ones - is social phenomenology as developed by Grathoff. Contrary to Luckmann, Grathoff asserts strong connections between sociology and phenomenological life-world analysis. At the same time, he gives more attention to theoretical and philosophical questions than Psathas. Grathoff treated the idea of anchoring the social sciences in the life-world category as an open question deserving further exploration and discussion. As a proponent of middle-range theory and a researcher interested in the category of milieu, he emphasised that Lebenswelt is always experienced in a concrete and sensory manner. The influence of Grathoff's thought is as broad as his scholarly contacts and as rich as his academic résumé - it extends across the United States, Western and East-Central Europe, and Japan.

Tadeusz Szawiel's remarkably relevant and thought-provoking essay validates Grathoff's strong belief in the openness of the discussion about the category of Lebenswelt - its epistemological, existential, and ontological meanings. Szawiel suggests differentiating between the life-world as an object of theory and as a life-horizon. By doing so, he touches on a key question, perhaps even an aporia, of studying the human world: the rela- 
tions between objectification - an indispensable component of theoretical cognition - and life, inscribed in some horizon and inseparable from it. Life, as long as it remains "live," defies complete cognitive objectification. Complex relations are thus revealed between exploring and experiencing the world ("being-in-the-world"), which cannot be reduced to the question of the world's cognitive "unclarity." Literary references to Joseph Conrad's Lord Jim and Herman Melville's Bartleby, the Scrivener, Nietzschean reflections On the Uses and Disadvantages of History for Life, and Heidegger's hermeneutics - including his interpretation of the biblical tree of life and cognition - create the background and substance of Szawiel's reflections. They lead to a conclusion that, in my opinion, it would be a form of disloyalty to Szawiel to reveal, as his original argument is worth pursuing with him.

A completely different perspective - not transcendental but material and corporeal - is introduced by Ingeborg Helling, who seeks to strengthen the phenomenological concept of intersubjectivity in contemporary neuroscience, particularly the theory of mirror neurons. Helling refers to the works of Vittorio Gallese, an outstanding Italian physiologist from Par$\mathrm{ma}$ and co-discoverer of mirror neurons. Gallese points to the biological dimension of intersubjectivity - its (inter)bodily foundation, grounded in the prelinguistic, functional mechanism of "embodied simulation" which enables "social cognition." At the same time, Helling refers to the luminaries of phenomenological thought (Franz Brentano, Edmund Husserl, Aron Gurwitsch, Jan Patočka, Edith Stein, and Maurice Merleau-Ponty) and key thinkers for the category of intersubjectivity. One may wonder whether this is an attempt at the "naturalisation" of phenomenology or, as Hilling prefers to see it, a "phenomenologisation" of neuroscience. However, these references can be treated as a starting point for reflection on another historical re-evaluation - following the anti-positivist turn - of the relations between the life sciences and the social sciences and humanities. In my opinion, neuroscience presents us with much more significant and interesting challenges than sociobiology, which was prominent mostly in the 1970s but is still influential, and more recently, evolutionary psychology. Regrettably, the author does not refer to the ongoing critique of the theory of mirror neurons, which questions its propensity for making interspecies extrapolations (see Hickok 2014).

Gallina Tasheva, whose essay concludes the first part of the volume, aims to draw sociologists' attention to the Heideggerian category of "being with" - putting emphasis on the "with." The author refers to Grathoff's work The Structure of Social Inconsistencies (1970), which discusses the incon- 
sistent and paradoxical character of human behaviour. The article attempts to overcome the dichotomies of individual and society, and of methodological individualism and holism, since the existing theoretical proposals, although formulated by outstanding scholars, seem insufficient to the author.

The second part of the book ("Symbolic Transcendence, State Power, and the Person") contains analyses of heterogenic material. The studies are concerned with questions such as the phenomenology of self-education, humiliation, self-transcendence, and transformations of state symbolism. Steven Vaitkus emphasises the cognitive relevance of the category of "symbolic transcendence" for the theoretical study and empirical analysis of culture. This concept served as a starting point for Schütz's and Karl Jaspers's symbol theory. Vaitkus follows the path where their thoughts meet. In this context, it is worth mentioning another of Schütz's works, entitled Symbol, Reality and Society, which he wrote at the end of his life and which is important for researchers of culture. Analysing personal documents, Fritz Schütze demonstrates the imposition of artificial stratification on the structures of everyday life by a socialist state (the GDR), and studies the consequences of these processes. Elżbieta Hałas, on the other hand, reports on the transformation of state symbolism. Dennis Smith, by analysing four cases of political prisoners in different places, times, and regimes (Oscar Wilde, Jean Améry, Nelson Mandela, and Aung San Suu Kyi), aims to arrive at a heuristic of humiliation. He examines individual reactions to humiliation and shows how it causes different - sometimes even drastic - reactions which are hard to predict or determine: from escapism, whose most extreme form is suicide, to conciliation. Lorenza Gattamorta addresses the question of self-transcendence in the age of contingency by comparing Peter L. Berger's and Hans Joas's scholarship (the latter is a well-known expert and propagator of pragmatism). The two scholars represent different intellectual traditions and thus differ in their analyses and opinions on contemporary cultural pluralism, secularisation, and universal values - questions discussed by Gattamorta. The term self-transcendence, in accordance with Joas's proposal, is understood here as a type of concrete experience which has the potential to become universalised.

The last part of the volume ("Communication and Various Cultures of Knowledge") considers the constructivist and communicative aspects of knowledge and its social status. According to Hubert Knoblauch, profound technological transformations are not limited to media changes, but they greatly impact the structures of contemporary society in toto (see Hałas 
2016: 194). In referring to Berger's and Luckmann's social constructivism, Jürgen Habermas's theory of communicative action, and Grathoff's suggestion to treat intersubjectivity as a necessary egological condition of socialisation and social phenomena, Knoblauch advances a concept of communicative constructivism and society. I assume that contemporary scholars of media and culture will find the proposal to confront communicative culture with communicative society both interesting and challenging. Marek Czyżewski proves that referring to Schütz's famous essay on Don Quixote (1964) is still worthwhile. Written over fifty years ago, this phenomenological study of the 400-year-old literary masterpiece remains a source of creative inspiration for sociological analyses of contemporary life. Czyżewski, who situates Schütz's interpretation on an extensive map of interpretations of Miguel de Cervantes's works, suggests that the originality of Schütz's analysis is insufficiently appreciated. Furthermore, Schütz's reading does not lose its value and significance for the phenomenological theory of multiple realities. In a paper full of biographical themes, Grathoff's friend, Ulf Matthiesen, demonstrates how to apply phenomenological categories in urban studies. Ewa Nowicka debates the opportunities and limitations of intercultural communication in conducting anthropological research. She compares two models of practising anthropology and their approaches to reflexivity by analysing Paul Rabinow's and Pierre Bourdieu's works based on their respective field studies in Morocco. It is worth noticing that at present Rabinow is distancing himself from interpretative anthropology, and it is difficult to define his position clearly (Rabinow 2006). Rafał Wierzchosławski discusses the role of experts in democratic societies, as well as the differences and similarities of the worlds inhabited by experts and citizens. He regards the works of Florian Znaniecki (author of The Social Role of the Man of Knowledge) and Schütz (The Well-Informed Citizen: An Essay on the Social Distribution of Knowledge) as precursors of experts' studies. ${ }^{2}$ Wierzchosławski applies the category of the life-world and Grathoff's milieu analysis in studying the roles played by experts in different domains of social life and before different audiences.

The authors of this volume prove that phenomenology still offers possibilities for thinking about social life and culture. They show that the challenges and transformations of the contemporary world - along with the present condition of the humanities and social sciences, which are of-

\footnotetext{
${ }^{2}$ Bruno Latour refers to John Dewey and Walter Lipmann's discussion, which introduces interesting themes to the debate on the role of experts. See Dewey 1954 [1927]: 131-133, 143, 149, and Lippman 1993 [1925].
} 
ten perceived as being in crisis - give validity to the postulate of rethinking the phenomenological category of Lebenswelt and intersubjectivity for epistemological and ontological justifications. Phenomenology underlines the experiential character of the social. The sense of experience cannot be explained, but it might be illuminated "from within." When reflecting on the relations between phenomenology and sociology, Lyotard remarked that "in any case of causation, research into originary sociality entails only that the definition of sociality come prior to the examination of its concrete forms" (1991: 104). I think in the case of this publication we are dealing with an attempt to articulate more comprehensively the sense of experiences which thus far have remained muted.

Bibliography:

/// Dewey J. 1954 [1927]. The Public and Its Problems, Swallow Press.

/// Grathoff R. 1970. The Structure of Social Inconsistencies: A Contribution to a Unified Theory of Play, Game, and Social Action. Martinus Nijhoff.

/// Hałas E., ed. 2016. Life-World, Intersubjectivity and Culture: Contemporary Dilemmas, Peter Lang.

/// Heidegger M. 1969. "Mein Weg in Phänomenologie," [in:] M. Heidegger, Zur Sache des Denkens, Niemeyer, pp. 81-90.

/// Hickok G. 2014. The Myth of Mirror Neurons: The Real Neuroscience of Communication and Cognition, W.W. Norton \& Company.

/// Kil A., Małczyński J., Wolska D., eds. 2015. Prace Kulturoznawcze XVIII. Kultura nie-lud₹ka, Wydawnictwo Uniwersytetu Wrocławskiego.

/// Lippmann W. 1993 [1925], The Phantom Public, Transaction Publishers.

/// Lyotard J-M. 1991 [1954]. Phenomenology, transl. B. Beakley, SUNY Press.

/// Przyłębski A. 2003. "Przyszłość fenomenologii. Rozmowa z Ferdinandem Fellmannem," Fenomenologia, vol. 1(1), pp. 37-48.

/// Rabinow P. 2006. "Steps Toward an Anthropological Laboratory," ARC Concept Note, vol. 1, http://anthropos-lab.net/wp/publications/2007/08/ conceptnoteno1.pdf, accessed 27.07.2016. 
/// Raulet G. 2006. La philosophie allemande depuis 1945, Armand Colin.

/// Schütz A. 1964. "Don Quixote and the Problem of Reality," [in:] A. Schütz, Collected Papers II: Studies in Social Theory, Martinus Nijhoff, pp. 136-158.

/// Dorota Wolska - professor at the Institute of Cultural Studies at the University of Wrocław, chair of the Theory of Culture Section, editor of Prace Kulturoznawcze and head of the Laboratory of the Contemporary Humanities. Her areas of research are the philosophy of the humanities, culture theory, and aesthetics. She recently published Odzyskać doswiadcrenie [To Recover Experience] and co-edited Kultura nie-ludvea [Non-Human Culture], a special issue of Prace Kulturoznawcze.

Email: dorota.wolska@uwr.edu.pl 